PLASTIC METHODS FOR STEEL AND CONCRETE STRUCTURES 


\section{Other titles of related interest}

Civil Engineering Contract Administration and Control, Second Edition

I. H. Seeley

Civil Engineering Materials, Fifth Edition

N. Jackson and R. Dhir (Editors)

Civil Engineering Quantities, Fifth Edition

I. H. Seeley

Finite Elements - A gentle introduction

D. J. Henwood and J. Bonet

Fundamental Structural Analysis

W. J. Spencer

Highway Traffic Analysis and Design, Third Edition

R. J. Salter and N. Hounsell

Reinforced Concrete Design, Fourth Edition

W. H. Mosley and J. H. Bungey

Reinforced Concrete Design to Euro Code 2

W. H. Mosley, R. Hulse and J. H. Bungey

Soil Mechanics - Principles and Practice

G. Barnes

Structural Mechanics

J. Cain and R. Hulse

Surveying for Engineers, Third Edition

J. Uren and W. F. Price

Understanding Hydraulics

L. Hamill

Understanding Structures

Derek Seward 


\title{
Plastic Methods for Steel and Concrete Structures
}

\author{
Stuart S. J. Moy \\ Department of Civil and Environmental Engineering \\ University of Southampton
}

Second Edition

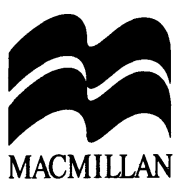


(C) Stuart S. J. Moy 1981, 1996

All rights reserved. No reproduction, copy or transmission of this publication may be made without written permission.

No paragraph of this publication may be reproduced, copied or transmitted save with written permission or in accordance with the provisions of the Copyright, Designs and Patents Act 1988, or under the terms of any licence permitting limited copying issued by the Copyright Licensing Agency, 90 Tottenham Court Road, London W1P 9HE.

Any person who does any unauthorised act in relation to this publication may be liable to criminal prosecution and civil claims for damages.

\section{First edition 1981}

Second edition 1996

\section{Published by}

\section{MACMILLAN PRESS LTD}

Houndmills, Basingstoke, Hampshire RG21 6XS

and London

Companies and representatives

throughout the world

ISBN 978-0-333-64177-4

ISBN 978-1-349-13810-4 (eBook)

DOI 10.1007/978-1-349-13810-4

A catalogue record for this book is available from the British Library. 


\section{Contents}

Preface ix

Notation $\quad$ xi

1 Some General Concepts 1

1.1 Introduction 1

1.2 Mild steel - the almost perfect material for plastic analysis $\quad 1$

1.3 How structures behave under varying load 4

$\begin{array}{lll}1.4 & \text { Summary } & 15\end{array}$

2 Plastic Bending $\quad 16$

$\begin{array}{lll}2.1 & \text { Introduction } & 16\end{array}$

2.2 What happens to a beam when it bends? 16

$\begin{array}{ll}2.3 \text { Calculation of the plastic moment } & 20\end{array}$

2.4 Why the plastic moment and plastic hinge are idealisations 23

2.5 A further complication 28

2.6 Factors which can alter the plastic moment 29

2.7 How the above theory is used practically 35

$\begin{array}{lll}2.8 & \text { Summary } & 36\end{array}$

$\begin{array}{ll}\text { Problems } & 36\end{array}$

3 Collapse of Simple Frames

$\begin{array}{ll}3.1 \text { Introduction } & 39\end{array}$

3.2 The behaviour of a portal frame under increasing load 39

3.3 The theorems of plastic analysis 44

3.4 The number of hinges required in a mechanism 45

3.5 Free and reactant BM method for finding collapse loads $\quad 46$

3.6 The virtual work method for finding collapse loads 53

$\begin{array}{lll}3.7 & \text { Summary } & 75\end{array}$

$\begin{array}{ll}\text { Problems } & 77\end{array}$ 
4 Limit Analysis $\quad 80$

$\begin{array}{ll}4.1 \text { Introduction } & 80\end{array}$

4.2 Elementary mechanisms $\quad 84$

4.3 Combination of mechanisms $\quad 85$

$\begin{array}{llr}4.4 & \text { Summary } & 99\end{array}$

$\begin{array}{lr}\text { Problems } & 100\end{array}$

5 Deflections and Stability 103

$\begin{array}{lll}5.1 \text { Introduction } & 103\end{array}$

$\begin{array}{ll}5.2 \text { Calculation of deflections } & 105\end{array}$

5.3 The effect of deflection on the collapse load 110

$\begin{array}{lll}5.4 \text { Summary } & 128\end{array}$

$\begin{array}{ll}\text { Problems } & 128\end{array}$

6 Design Using Plastic Theory 133

6.1 Introduction 133

6.2 Load factors 134

6.3 Design of a simply supported beam 135

6.4 Continuous beam design by plastic theory 136

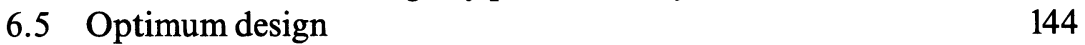

6.6 Direct design of pitched portal frames 155

$\begin{array}{lll}6.7 & \text { Summary } & 162\end{array}$

Problems 163

7 Application of Plastic Methods to Reinforced Concrete Structures 167

$\begin{array}{lll}7.1 & \text { Introduction } & 167\end{array}$

7.2 The behaviour of reinforced concrete in bending 167

7.3 What happens if there is insufficient plastic rotation capacity? 176

7.4 The compromise adopted in Codes of Practice 177

$\begin{array}{lll}7.5 & \text { Summary } & 186\end{array}$

$\begin{array}{ll}\text { Problems } & 187\end{array}$

8 Yield-line Analysis and the Hillerborg Strip Method for Reinforced $\begin{array}{lr}\text { Concrete Slabs } & 188\end{array}$

$\begin{array}{lll}8.1 \text { Introduction } & 188\end{array}$

8.2 Yield-line theory 188

8.3 Hillerborg's strip method 223

$\begin{array}{lll}8.4 & \text { Summary } & 235\end{array}$

Problems $\quad 236$

$\begin{array}{ll}\text { Appendix A : Yield Criteria } & 240\end{array}$

Appendix B: A Redundancy Test $\quad 247$

Appendix C : Bending Moment Diagrams 249 
References

Solutions to Problems

Index 


\section{Preface}

In the preface to the first edition I said that this book owes much to the many students, both undergraduate and postgraduate, who have sat patiently and attentively through my lectures on plastic methods. This continues to be the case with the second edition. Questions and discussion during and outside the lectures have shown that certain aspects of the subject consistently create difficulties and have also pointed to where my explanations in the first edition were not clear. Perhaps I flatter myself that the difficulties in the subject are not due to shortcomings in my teaching technique, but because certain points need greater attention than is possible in a lecture. It has been my intention to provide that extra attention in this book.

The second edition was harder to write than the first - it has become difficult to find and justify the time required. However, there were several motivations that made it possible. Firstly, I had identified various shortcomings in the original which was also rather dated in places. Secondly, things have moved on in the design of steel and concrete structures. New British, European and US design codes have been introduced in the last ten years which are explicit in how plastic methods should be used. It really was essential to include some of that material. Finally, I came under pressure from my publisher!

The book is intended to cover most of the requirements of students at both undergraduate and postgraduate levels. It will also be useful to practising engineers who use plastic methods. The emphasis throughout is on the ideas behind, and the application of, plastic methods, rather than their mathematical justification (I have given references to appropriate texts and papers for this). To achieve my aim I have simplified some of the arguments (as was pointed out in a conference paper shortly after the publication of the first edition). I am sorry if my approach offends the purists.

The book is divided into eight chapters. The first two deal with the concepts of plastic behaviour, and plastic bending in particular. Chapters 3 and 4 describe the techniques for finding the collapse loads of steel frames. Chapter 5 looks at the effects of deflections, imperfections and instability on the collapse of structures. These 'secondary' effects are complex and a detailed study is be- 
yond the scope of the book. However, I have endeavoured to give a general explanation and have then shown how these effects are covered in design. Chapter 6 shows how plastic methods are used in the design of steel structures, looking in detail at beams and portal frames. Chapters 7 and 8 deal with reinforced concrete structures: Chapter 7 examines the problems of applying plastic methods to concrete frames and the compromises that have to be made in design codes, and Chapter 8 describes the powerful yield-line and strip methods for slabs. Since the publication of the first edition, computers have made an enormous impact on technology. This edition shows how computing can be applied to the use of plastic methods.

As a rough guide based on my own courses, the first three chapters provide a solid introduction which would be appropriate to second year undergraduate level, while Chapters 4,6 and parts of 5,7 and 8 would be suitable for a third or fourth year course. A postgraduate course could make use of all the material.

I have tried to be consistent in the layout of each chapter. There is an introduction which gives, where appropriate, the background theory. The meat of each chapter is usually presented in a series of examples which have been carefully graded. The first example introduces the ideas in the simplest possible manner, while subsequent ones introduce new ideas or examine those areas that can cause difficulties. It is important that the reader realises that the examples introduce new ideas as well as illustrate earlier ones. The whole is then brought together in a summary. At the end of each chapter (apart from the first) there is a series of examples, designed to bring out the various points made in the chapter. I strongly encourage the reader to work through the examples, preferably in order. Practice really is the best way of getting to grips with plastic methods. 


\section{Notation}

It has been convenient for the same symbols to have different meanings or for similar things to have different symbols. These are all noted here, but are also defined in the text. It has been necessary to add suffixes to various symbols to indicate specific meanings - these are always defined in the text.

\section{Forces}

$C, T \quad$ compressive and tensile forces from bending stress blocks

$F$

$N$

$P$

$P_{\mathrm{c}}$

$P_{\text {cr }}$

$P_{\mathrm{p}}$

$q$

SF

UDL

$V, H$

$W$

$w, Q$

$\lambda$

$\lambda^{\prime}$

$\lambda_{\mathrm{c}}$

$\lambda_{\mathrm{e}}$

$\lambda_{1}$

$\lambda_{\mathrm{u}}$

\section{Moments}

\section{BM}

BMD axial member force in a pin-jointed truss

shear force in a member in bending

axial force in a member in bending

axial force at collapse

buckling force

squash load

distributed loading on a slab

shear force (abbreviation)

uniformly distributed load (abbreviation)

vertical and horizontal applied loads (forces) and reactions

applied load

line load

load factor

change in load factor

collapse load factor

buckling load factor

lower bound (under-estimate) to the collapse load factor

upper bound (over-estimate) to the collapse load factor 
FEM fixed-end moment (abbreviation)

$M_{\mathrm{e}} \quad$ bending moment found by plastic analysis

$M_{\mathrm{n}} \quad$ moment per unit length about an axis along yield line

$M_{\mathrm{p}} \quad$ plastic moment

$M_{\mathrm{p}}^{\prime} \quad$ reduced plastic moment

$\beta_{\mathrm{b}} \quad$ redistribution ratio (BS 8110 notation)

$\delta \quad$ redistribution factor (Eurocode 2 notation)

\section{Material and Section Properties}

A

$A_{\mathrm{s}}$

$B, b$

$D, d$

$d$

$d_{1}$

E

$E_{\text {sh }}$

$f_{\mathrm{ck}}$

$f_{\text {cu }}$

G

$G^{\prime}$

g

I

$l$

$l / r$

$r$

$S$

$T$

$t$

$x$

$Z$

$\gamma$

$\epsilon$

$\sigma$

$\sigma_{\mathrm{y}}$

$\tau$

$\tau_{\mathrm{y}}$

cross-sectional area

cross-sectional area of steel reinforcement

width

depth

effective depth of tensile reinforcement

effective depth of compression reinforcement

Young's (elastic) modulus

slope of stress-strain curve at the start of strain hardening characteristic cylinder strength of concrete

characteristic cube strength of concrete

structure weight function

variable part of weight function

weight per unit length

second moment of area

effective length

slenderness ratio

radius of gyration $[=\sqrt{ }(I / A)]$

plastic modulus

flange thickness

web thickness, thickness

depth to neutral axis (axis of zero strain) in a concrete beam

elastic (section) modulus

shear strain

direct strain

direct stress

yield stress

shear stress

yield shear stress

\section{Lengths and Displacements}
$e$
eccentricity
$L, h$
overall dimensions 


$\begin{array}{ll}l, a, b & \text { dimensions } \\ R & \text { radius, radius of curvature } \\ x, y, z & \text { coordinate axes; distances in coordinate directions } \\ \alpha, \beta, \gamma, \theta, \phi & \text { angles; rotations } \\ \Delta, \delta & \text { displacements, deflections } \\ \chi & \text { curvature }\end{array}$

\section{General}

$\begin{array}{ll}c, n, k & \text { constants, ratios } \\ i & \text { ratio of positive and negative moments of resistance } \\ K & \text { Hillerborg correction factor } \\ m & \text { number of elementary mechanisms } \\ n & \text { number of plastic hinges } \\ p & \text { number of possible plastic hinges } \\ r & \text { degree of redundancy (indeterminacy) } \\ s, c, m & \text { stability functions } \\ \text { YL } & \text { yield line (abbreviation) } \\ \mu & \text { measure of orthotropy in slabs }\end{array}$

\section{Sign Convention}

The most convenient sign conventions have been used. Thus tensile stresses, strains and axial forces are assumed positive except in Chapter 5 where compression is assumed to be positive. Bending moments are plotted on the side of the member that is in tension. Tension on the underside of a beam or to the left of a column, as drawn, is assumed to be caused by a positive bending moment. 